\title{
Soldering of Mg Joints Using Zn-AI Solders
}

\author{
TOMASZ GANCARZ, KATARZYNA BERENT, WOJCIECH SKUZA, \\ and KATARZYNA JANIK
}

\begin{abstract}
Magnesium has applications in the automotive and aerospace industries that can significantly contribute to greater fuel economy and environmental conservation. The $\mathrm{Mg}$ alloys used in the automotive industry could reduce mass by up to 70 pct, providing energy savings. However, alongside the advantages there are limitations and technological barriers to use $\mathrm{Mg}$ alloys. One of the advantages concerns phenomena occurring at the interface when joining materials investigated in this study, in regard to the effect of temperature and soldering time for pure $\mathrm{Mg}$ joints. Eutectic $\mathrm{Zn}-\mathrm{Al}$ and $\mathrm{Zn}-\mathrm{Al}$ alloys with 0.05 (wt pct) Li and 0.2 (wt pct) $\mathrm{Na}$ were used in the soldering process. The process was performed for 3, 5, and 8 minutes of contact, at temperatures of $425{ }^{\circ} \mathrm{C}, 450{ }^{\circ} \mathrm{C}, 475{ }^{\circ} \mathrm{C}$, and $500{ }^{\circ} \mathrm{C}$. Selected, solidified solder-substrate couples were cross-sectioned, and their interfacial microstructures were investigated by scanning electron microscopy. The experiment was designed to demonstrate the effect of time, temperature, and the addition of $\mathrm{Li}$ and $\mathrm{Na}$ on the kinetics of the dissolving $\mathrm{Mg}$ substrate. The addition of $\mathrm{Li}$ and $\mathrm{Na}$ to eutectic $\mathrm{Zn}-\mathrm{Al}$ caused to improve mechanical properties. Higher temperatures led to reduced joint strength, which is caused by increased interfacial reaction.
\end{abstract}

https://doi.org/10.1007/s11661-018-4617-0

(C) The Author(s) 2018

\section{INTRODUCTION}

Changes to the electrical engine, which can bring about a reduction in its mass, are of significant interest to the automotive industry. ${ }^{[1,2]} \mathrm{Al}$ and $\mathrm{Mg}$ alloys are increasingly used to reduce structural mass. ${ }^{[3]}$ Taking into account the lightest applications, the density of structural materials $\left(\rho_{\mathrm{Al}}=2.7 \mathrm{~g} \mathrm{~cm}^{-3}, \quad \rho_{\mathrm{Mg}}=1.7 \mathrm{~g} \mathrm{~cm}^{-3}\right)^{[4]}$ is very important. The aerospace industry's requirements for lightweight materials to operate under increasingly demanding conditions calls for reduced mass and improved mechanical properties. Compared to the $\mathrm{Al}$ alloys, the $\mathrm{Mg}$ alloys display better physical and mechanical properties, such as high strength-to-weight ratio, high damping capacity, and a high recycling potential. These facts could have a decisive effect on the application of $\mathrm{Mg}$ alloys in the automotive, electronics, and aerospace industries. However, similar atomic mass and melting temperature in the $\mathrm{Al}-\mathrm{Mg}$ system formed brittle intermetallic compounds (IMCs) such as $\mathrm{Al}_{3} \mathrm{Mg}_{2}$ and $\mathrm{Al}_{12} \mathrm{Mg}_{17}$ in the solidified metal. ${ }^{[5]}$ Furthermore, joining the $\mathrm{Al}$ with $\mathrm{Mg}$ alloys is difficult, but possible using several

TOMASZ GANCARZ, WOJCIECH SKUZA, and KATARZYNA JANIK are with the Institute of Metallurgy and Materials Science, Polish Academy of Sciences, 30-059 Krakow, Poland. Contact e-mail: t.gancarz@imim.pl KATARZYNA BERENT is with the AGH University of Science and Technology, Academic Centre for Materials and Nanotechnology, 30-059 Krakow, Poland.

Manuscript submitted May 24, 2017.

Article published online April 18, 2018 techniques such as resistant spot welding, ${ }^{[3,6]}$ reactive brazing, ${ }^{[7]}$ laser welding, ${ }^{[8]}$ ultrasonic-assisted soldering, ${ }^{[9]}$ and so on. In order to eliminate the negative effect of $\mathrm{Mg}-\mathrm{Al} \mathrm{IMCs}$ on the strength of the joints, an interlayer intended to block the formation of brittle $\mathrm{IMC}^{[3]}$ was used. $\mathrm{Zn},{ }^{[3]} \mathrm{Sn}-\mathrm{Zn}$ alloys ${ }^{[10]} \mathrm{Mg}-\mathrm{Zn}-\mathrm{Al}$, and $\mathrm{Mg}-\mathrm{In}-\mathrm{Zn}^{[11]}$ were used to join $\mathrm{Al}$ with $\mathrm{Mg}$ alloys.

In view of the high oxidation and corrosion of $\mathrm{Mg}$ alloys, an addition characterized by high electrode potential compared to $\mathrm{Mg}(-2.37 \mathrm{~V})^{[9]}$ is made to the solder. In this case, the layers of chromium and Teflon protected the $\mathrm{Mg}$ against corrosion. ${ }^{[12]} \mathrm{Mg}$ alloys soldered at high temperature displayed worse mechanical properties, so the joining process temperature should be lower than $450{ }^{\circ} \mathrm{C}$. For lower temperature soldering, flux was used to increase wettability, which also protected the alloy surface from the formation the stable magnesium oxide. ${ }^{[1]}$ The application of an $\mathrm{Zn}$ interlayer when joining $\mathrm{Al} / \mathrm{Mg}$ alloys using resistant spot welding caused a reduction in welding current compared with traditional welding. ${ }^{[3]} \mathrm{Al}$ dissolving into the fusion zone caused the increased formation of solid particles, which improves the quality of the joints. ${ }^{[3]} \mathrm{Sn}-\mathrm{Zn}$ used at low temperatures for soldering $\mathrm{Al} / \mathrm{Mg}$ joints caused the amount of $\mathrm{Zn}$ to rise by up to $30 \mathrm{pct}$, increasing shear strength. In addition, the dispersive distribution of the Al-Sn-Zn solid solution within the solder reduced the brittleness of the joint, thus greatly improving the mechanical properties. The conducted study, joining AZ31B alloy using $\mathrm{Zn}$, caused the formation of an IMC from the $\mathrm{Zn}-\mathrm{Mg}$ system at the interface. However, a higher cooling rate 
was beneficial for increasing the tensile shear strength of joints, ${ }^{[9]}$ as it caused the formation of equiaxed dendrites and refined eutectic structure.

To show the influence at the interface during soldering, research should be carried out for pure $\mathrm{Mg}$. This study demonstrates the effect on the microstructure of joints and mechanical properties of joining pure $\mathrm{Mg}$ using eutectic $\mathrm{Zn}-\mathrm{Al}$ and $\mathrm{Zn}-\mathrm{Al}$ alloys with additions of $\mathrm{Li}$ and $\mathrm{Na}$.

\section{EXPERIMENTAL}

Cast alloys of eutectic $\mathrm{Zn}-\mathrm{Al},{ }^{[13]} \mathrm{Zn}-\mathrm{A} 10.05 \mathrm{Li},{ }^{[13]}$ and $\mathrm{Zn}-\mathrm{A} 10.2 \mathrm{Na}^{[14]}$ were used in this study, and the solder was tested while soldering $\mathrm{Cu}$ substrate. ${ }^{[15,16]}$ The cast alloys were rolled to a thickness of $1 \mathrm{~mm}$ and cut into $8 \times 10 \mathrm{~mm}$ pieces. The base material used for soldering was pure $\mathrm{Mg}$ (99.9 pct) with dimensions of $8 \times 4 \times 25 \mathrm{~mm}$. The $\mathrm{Mg}$ substrate and solder pieces were cleaned using emery paper and acetone before the soldering process, to remove the oxide from the surface. Soldering the $\mathrm{Mg}$ joints was carried out using the sessile drop method, ${ }^{[17]}$ with protective gas $\operatorname{Ar}(5 \mathrm{~N})$, for times of 3,5 , and 8 minutes of contact and at temperatures of $425^{\circ} \mathrm{C}, 450{ }^{\circ} \mathrm{C}, 475^{\circ} \mathrm{C}$, and $500{ }^{\circ} \mathrm{C}$. The samples were moved from the cold zone to the hot zone of the furnace, where a type $\mathrm{K}$ thermocouple was touching the bottom of the holder and the melting process was observed by CCD camera. After a predetermined time, the sample was moved to the cold zone, then removed and placed on a stone table. A special holder (the same as was used in Reference 18) was employed during the process, to keep together the $\mathrm{Mg}$ substrate. After the soldering process, the overflow of solder was gently removed in order to preserve the dimensions of the samples. Four samples were prepared for each temperature and time, three for testing of mechanical properties and one for microstructure observation. The specimens for cross section were mounted in resin, than grand and polished. Microstructural and elemental analyses were performed using scanning electron microscopy (FEI Quanta 3D FEG-SEM) coupled with energy dispersive X-ray spectrometry (EDS), in order to study the interfacial microstructure and IMCs occurring at the interface. For all samples, three measurements were made at different areas to improve statistics and to check the homogeneity of the joints. Mechanical tests were conducted with an INSTRON 6025 testing machine modernized by Zwick/Roell. Testing conditions were in accordance with ASTM A 264-03, with a strain rate of $0.00025(1 / \mathrm{s})$ at room temperature. The mechanical tests were performed for each of the joints with the eutectic $\mathrm{Zn}-\mathrm{Al}$ alloys, and with $\mathrm{Na}$ and $\mathrm{Li}$ additions, and three successful measurements were taken. After mechanical testing, the real area of the joints (the area of soldering between $\mathrm{Mg}$ substrates) was measured using CorelDraw with the GetArea module. The shear strength is calculated using the obtained force from mechanical tests divided by real area of the joints. The samples for the tests were taken after soldering, where the flow solder from the substrate was removed. The microhardness of the formed phases in the soldering region was measured by means of microhardness tests carried out at a load of $0.5(\mathrm{~N})$ and over a time of 15 (seconds).

\section{RESULTS}

\section{A. Microstructure Observation}

All the Mg joints were obtained under a suitable protective gas without flux. However, an experiment using flux and without protective gas was also performed. Fluxes such as ALU12, QJ201, F380Mg, and F390Mg caused the joints' mechanical properties to worsen, and even led to the joints themselves breaking. Taking this into account, a protective atmosphere was used instead of flux, and this resulted in stable joints. The microstructure is presented in Figure 1, for eutectic $\mathrm{Zn}-\mathrm{Al}$ and $\mathrm{Mg}$ joints after soldering for 3,5 , and 8 minutes of contact, at a temperature of $425^{\circ} \mathrm{C}$. The solder dissolved $\mathrm{Mg}$ substrates during the soldering process, and formed at the interface an interfacial $\mathrm{Mg}-\mathrm{Zn}$ layer, which was confirmed by the EDS analysis presented in Table I. With increasing soldering time, the $\mathrm{Mg}-\mathrm{Zn}$ layer grew. Furthermore, particles of $\mathrm{Mg}$ with a small amount of $\mathrm{Zn}$ dissolved inside the filler solder.

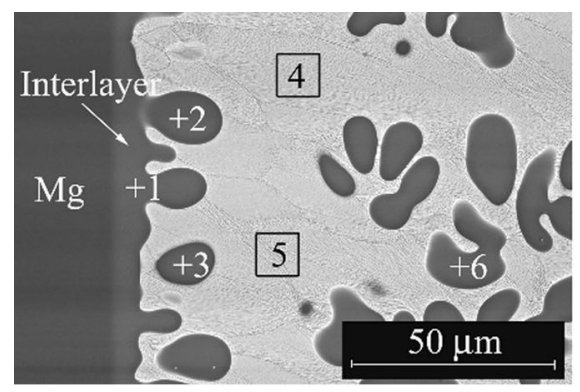

(a)

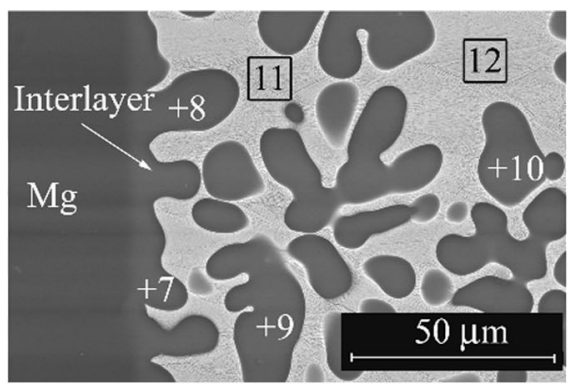

(b)

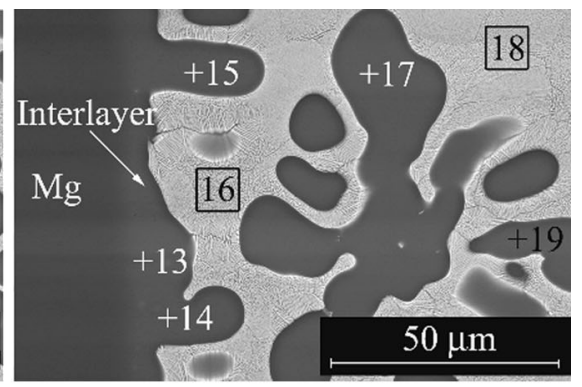

(c)

Fig. 1-Microstructure after soldering process for eutectic $\mathrm{Zn}-\mathrm{Al}$ and $\mathrm{Mg}$ joints for $(a) 3,(b) 5$, and $(c) 8$ min of contact, at a temperature of $425{ }^{\circ} \mathrm{C}$. The numbers in the figure denote the points of EDSs presented in Table I. 
The amount of $\mathrm{Al}$ is on the same level for all measured points, at around 2 to 3 (wt pct). However, the $\mathrm{Zn}$ in the $\mathrm{Mg}-\mathrm{Zn}$ particles increased slightly from the $\mathrm{Mg}$ substrate $(\sim 3 \mathrm{wt} \mathrm{pct})$ to inside the solder ( $\sim 8$ wt pct), which correlates with $\mathrm{Mg}$ dissolving in the solder. The Mg particles in all soldered joints were observed. Most importantly, the matrix of the solder changed from eutectic $\mathrm{Zn}-\mathrm{Al}$ to an $\mathrm{Mg}+\mathrm{MgZn}$ eutectoid structure. This reaction is correlated with the high amount of dissolved $\mathrm{Mg}$, which, according to the Mg-Zn phase diagram, ${ }^{[5]}$ formed the lamellar $\alpha-$ $\mathrm{Mg}+\mathrm{MgZn}$ eutectoid structure distributed on the boundary of the black $\alpha-\mathrm{Mg}$ solid solution in the soldering region. EDS analysis (Table I-gray area) shows that, with increasing time, the amount of $\mathrm{Mg}$ in these eutectoid areas also increases. According to the $\mathrm{Mg}-\mathrm{Zn}$ phase diagram, ${ }^{[5]}$ the $\mathrm{Mg}_{7} \mathrm{Zn}_{3}$ phase is formed by a eutectic reaction at $340{ }^{\circ} \mathrm{C}: \mathrm{L} \rightarrow \alpha-\mathrm{Mg}+\mathrm{Mg}_{7} \mathrm{Zn}_{3}$. Further reduction of temperature causes the formation

Table I. EDS Analysis of Marked Points in Fig. 1 of Soldering Joints with Increasing Time of 3, 5, and 8 Min at a Temperature of $425^{\circ} \mathrm{C}$

\begin{tabular}{lccr}
\hline & \multicolumn{3}{c}{ Weight Percent } \\
\cline { 2 - 4 } & MgK & AlK & ZnK \\
\hline 1 & 91.1 & 2.1 & 6.8 \\
2 & 90.5 & 2.1 & 7.4 \\
3 & 90.8 & 2.1 & 7.1 \\
4 & 49.4 & 3.2 & 47.4 \\
5 & 49.5 & 3.0 & 47.5 \\
6 & 90.0 & 2.0 & 8.0 \\
7 & 91.3 & 2.1 & 6.6 \\
8 & 90.9 & 2.4 & 6.7 \\
9 & 90.9 & 2.2 & 6.9 \\
10 & 90.5 & 2.2 & 7.3 \\
11 & 50.2 & 3.4 & 46.4 \\
12 & 50.1 & 3.6 & 46.3 \\
13 & 91.3 & 2.3 & 6.4 \\
14 & 92.0 & 2.3 & 5.7 \\
15 & 90.4 & 2.4 & 7.2 \\
16 & 54.0 & 3.6 & 6.4 \\
17 & 91.2 & 2.4 & 74.6 \\
18 & 51.6 & 3.8 & \\
19 & 90.5 & 2.5 & \\
\hline
\end{tabular}

of an $\mathrm{MgZn}$ phase by a eutectoid reaction at $325^{\circ} \mathrm{C}$ : $\mathrm{Mg}_{7} \mathrm{Zn}_{3} \rightarrow \alpha-\mathrm{Mg}+\mathrm{MgZn} .{ }^{[19]}$ However, in our case, $\mathrm{Mg}$ was dissolving and supplied to the melt solder, which is observed in the microstructure (Figure 1). With increasing time, a rising number of $\mathrm{Mg}$ particles is observed, with the highest being for $8 \mathrm{~min}$. A similar microstructure for all eutectic $\mathrm{Zn}-\mathrm{Al}$ and $\mathrm{Zn}-\mathrm{Al}$ with $\mathrm{Li}$ and $\mathrm{Na}$ alloys was observed. However, under the same conditions, the highest amount of dissolved $\mathrm{Mg}$ in the interface, and the greatest number of $\mathrm{Mg}$ particles for $\mathrm{Na}$ content, was observed for $\mathrm{Zn}-\mathrm{A} 10.05 \mathrm{Li}$ compared to eutectic Zn-Al (see Figure 2). In Figure 2, (a) Zn-Al, (b) $\mathrm{Zn}-\mathrm{A} 10.05 \mathrm{Li}$, and (c) $\mathrm{Zn}-\mathrm{A} 10.2 \mathrm{Na}$ joints after soldering at $450{ }^{\circ} \mathrm{C}$ and 8 minutes are presented.

Figure 3 shows the $\mathrm{Mg}$ joints soldered by eutectic $\mathrm{Zn}$-Al after 3 minutes and at temperatures of $450{ }^{\circ} \mathrm{C}$, $475^{\circ} \mathrm{C}$, and $500{ }^{\circ} \mathrm{C}$. With increasing temperature, the Al-Mg interlayers obtained greater thickness and a higher number of $\mathrm{Mg}$ inclusions are observed.

According to the $\mathrm{Mg}-\mathrm{Li}^{[20]}$ phase diagrams, Li content up to 5 (wt pct) dissolved in the solid solution. For $\mathrm{Na}$ content (in the whole range) as shown in $\mathrm{Mg}-\mathrm{Na},{ }^{[21]}$ the liquid occurring across almost the entire $\mathrm{Mg}$ range of $\mathrm{Mg}-\mathrm{Na}$ alloys after $97.8{ }^{\circ} \mathrm{C}$ probably accelerates the dissolving process of $\mathrm{Mg}$ substrates. The greatest dissolution with soldering time for $\mathrm{Li}$ and $\mathrm{Na}$-containing alloys compared to eutectic $\mathrm{Zn}-\mathrm{Al}$ is presented in Figure 4.

The measured thickness of the "interlayer" is dependent on the time. With increasing temperature and time, the thickness of the interlayer also increased. This effect caused the $\mathrm{Mg}$ substrate to dissolve by the grain boundary, and all grains to move to the solder, which is shown for Na content in eutectic Zn-Al in Figure 2(c). The data presented in Figure 4 confirm that, with time and temperature of soldering, the effect of dissolving $\mathrm{Mg}$ substrates is highest for $\mathrm{Na}$, then for $\mathrm{Li}$ additions, and lowest for eutectic $\mathrm{Zn}-\mathrm{Al}$.

The microstructure for $425^{\circ} \mathrm{C}$ is presented in Figure 1(a). With increasing temperature, the amount of dissolved $\mathrm{Mg}$ in the solder also increases. At the highest temperature $\left(500^{\circ} \mathrm{C}\right)$, dissolution of the $\mathrm{Mg}$ substrate by the grain boundary is observed after 3 minutes, to the same degree as after 8 minutes at a lower temperature, of $450^{\circ} \mathrm{C}$. For all alloys, eutectic $\mathrm{Zn}-\mathrm{Al}$, and $\mathrm{Zn}-\mathrm{Al}$ with $\mathrm{Li}$ and $\mathrm{Na}$ additions, the

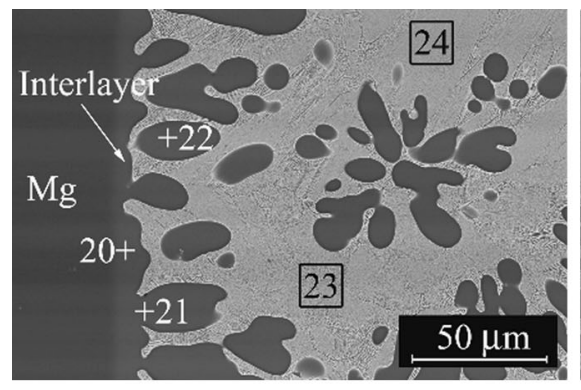

(a)

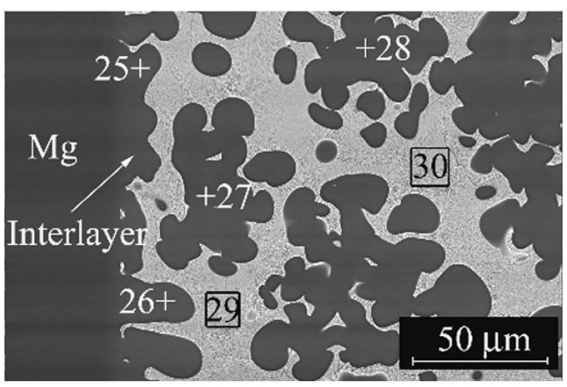

(b)

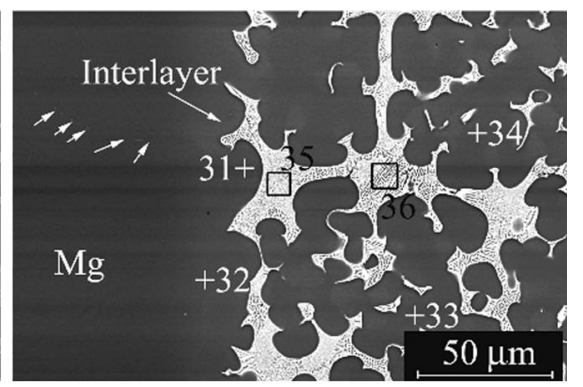

(c)

Fig. 2-Microstructure after soldering process for (a) Zn-Al, (b) Zn-Al0.05Li, (c) Zn-Al0.2Na, respectively, at $450{ }^{\circ} \mathrm{C}$ for 8 min. The numbers in the figure denote the points of EDSs presented in Table II. 
observed microstructures are similar. However, the thickness of the interlayer at the interface increases with additions of $\mathrm{Li}$ and $\mathrm{Na}$ compared to eutectic $\mathrm{Zn}-\mathrm{Al}$, as shown in Figure 4. For the highest soldering temperature, of $500{ }^{\circ} \mathrm{C}$, the dissolution of all $\mathrm{Mg}$ grains is observed for all alloys, which caused increasing consumption of the $\mathrm{Mg}$ substrate, an increase in the thickness of the interlayer, and a resulting increase in the thickness of the area of the joints.

\section{B. Mechanical Properties}

At first, tensile tests were used to determine the shear strength of joints. ${ }^{[9,10,19]}$ However, during our tensile testing the sample was twisted, causing the $\mathrm{Mg}$ substrate to break close to the soldering zone, which increased the errors in calculating the shear strength of the joints. As a result, a different method of tensile testing was proposed in order to obtain the correct shear strength of joints. As described in Reference 22, the soldered pad is sheared

Table II. EDS Analysis of Marked Points in Fig. 2 of Soldering Mg Joints at a Temperature of $450{ }^{\circ} \mathrm{C}$ and a Time of $8 \mathrm{Min}$, by Eutectic Zn-Al, Zn-Al0.05Li, and Zn-Al0.2Na

\begin{tabular}{lccr}
\hline & \multicolumn{3}{c}{ Weight Percent } \\
\cline { 2 - 4 } & MgK & AlK & ZnK \\
\hline 20 & 91.5 & 1.9 & 6.6 \\
21 & 90.9 & 1.9 & 7.2 \\
22 & 90.4 & 1.9 & 7.7 \\
23 & 49.7 & 3.0 & 47.3 \\
24 & 49.4 & 3.0 & 47.6 \\
25 & 92.7 & 1.8 & 5.5 \\
26 & 92.8 & 1.7 & 5.5 \\
27 & 92.3 & 1.7 & 6.0 \\
28 & 92.7 & 1.7 & 5.6 \\
29 & 49.1 & 3.1 & 47.8 \\
30 & 48.7 & 3.0 & 5.3 \\
31 & 92.9 & 1.8 & 5.5 \\
32 & 92.6 & 1.9 & 6.0 \\
33 & 92.2 & 1.8 & 6.0 \\
34 & 92.2 & 1.8 & 45.8 \\
35 & 52.4 & 3.0 & \\
36 & 51.0 & 3.2 & \\
\hline
\end{tabular}

during applied force. Such a solution ensuring the correct shear strength of joints was applied.

To determine the shear strength of joints, the device presented in Reference 22 and Figure 5 was used, along with samples of different diameters. However, especially for the high temperature of $500{ }^{\circ} \mathrm{C}$, the $\mathrm{Mg}$ pads are dissolved by the solder during the soldering process, causing the area of interface reaction to move and expand. The obtained results for the shear strengths of joints with eutectic Zn-Al, Zn-A10.05Li, and $\mathrm{Zn}-\mathrm{A} 10.2 \mathrm{Na}$, after soldering times of 3,5 , and 8 minutes and for temperatures of $425^{\circ} \mathrm{C}, 450{ }^{\circ} \mathrm{C}, 475^{\circ} \mathrm{C}$, and $500{ }^{\circ} \mathrm{C}$ are presented in Figure 6 .

$\mathrm{Zn}-\mathrm{A} 10.2 \mathrm{Na}$ showed the highest shear strength value (50.7 MPa), followed by $\mathrm{Zn}-\mathrm{Al} 10.05 \mathrm{Li}$ (32.2 MPa) and eutectic $\mathrm{Zn}-\mathrm{Al}$ (28.2 MPa). For all solders, the highest values of shear strength of joints for temperatures of $425{ }^{\circ} \mathrm{C}, 450{ }^{\circ} \mathrm{C}$, and $475{ }^{\circ} \mathrm{C}$ were obtained for all times. These values are all similar and fall within error limits. For a soldering temperature of $500{ }^{\circ} \mathrm{C}$, shear strength reduces significantly, by as much as 50 pct, in all cases. Such behavior could be caused by the increasing

Table III. EDS Analysis of Marked Points in Fig. 4 of Soldering Joints with Increasing Temperatures of $450{ }^{\circ} \mathrm{C}$, $475^{\circ} \mathrm{C}$, and $500{ }^{\circ} \mathrm{C}$ and a Time of $3 \mathrm{Min}$

\begin{tabular}{lccr}
\hline & \multicolumn{3}{c}{ Weight Percent } \\
\cline { 2 - 4 } & MgK & AlK & ZnK \\
\hline 37 & 96.0 & 0.2 & 3.8 \\
38 & 95.2 & 0.2 & 4.6 \\
39 & 49.3 & 0.9 & 49.8 \\
40 & 49.9 & 0.9 & 49.2 \\
41 & 94.4 & 0.3 & 5.3 \\
42 & 95.5 & 0.6 & 3.9 \\
43 & 95.6 & 0.6 & 3.8 \\
44 & 95.7 & 0.5 & 3.8 \\
45 & 57.2 & 1.6 & 41.2 \\
46 & 56.0 & 1.6 & 42.4 \\
47 & 96.5 & 0.5 & 3.0 \\
48 & 95.5 & 0.6 & 3.9 \\
49 & 96.5 & 0.5 & 3.0 \\
50 & 96.4 & 0.5 & 3.1 \\
51 & 96.5 & 0.4 & 3.1 \\
52 & 55.4 & 1.7 & 42.9 \\
\hline
\end{tabular}

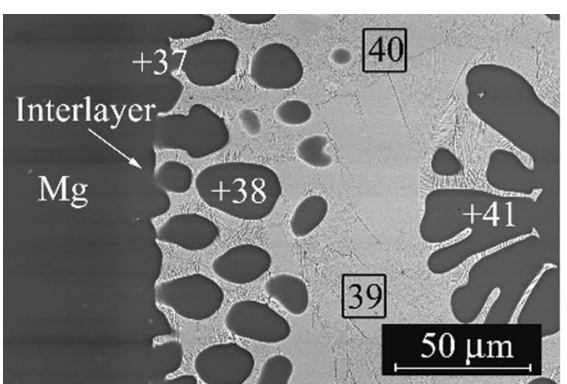

(a)

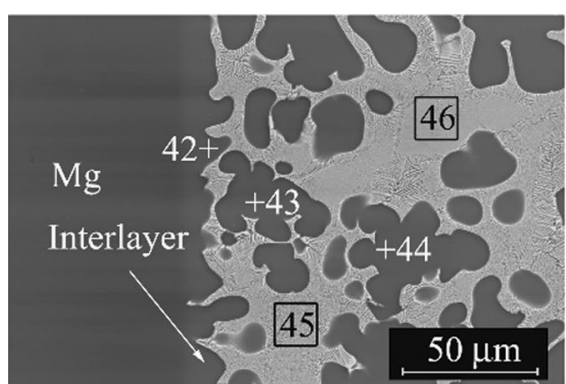

(b)

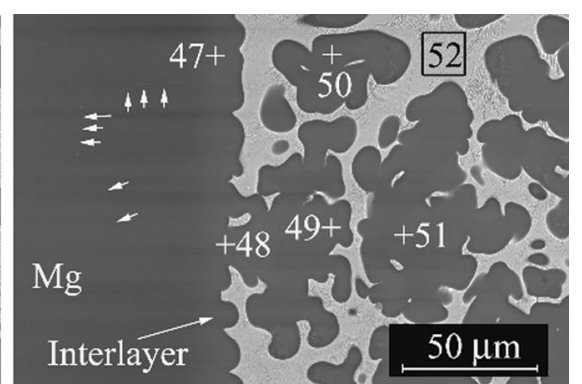

(c)

Fig. 3-Microstructure of eutectic $\mathrm{Zn}-\mathrm{Al}$ with $\mathrm{Mg}$ joints after soldering for 3 min at temperatures of $(a) 450$, (b) 475 , and $(c) 500{ }^{\circ} \mathrm{C}$. The numbers in the figure denote the points of EDSs presented in Table III. 


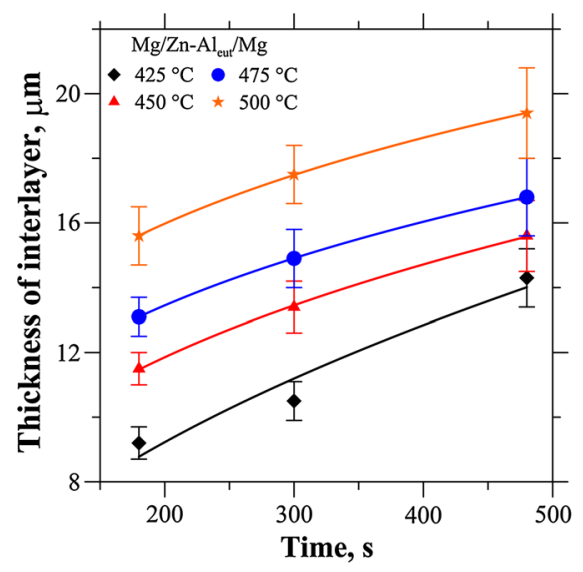

(a)

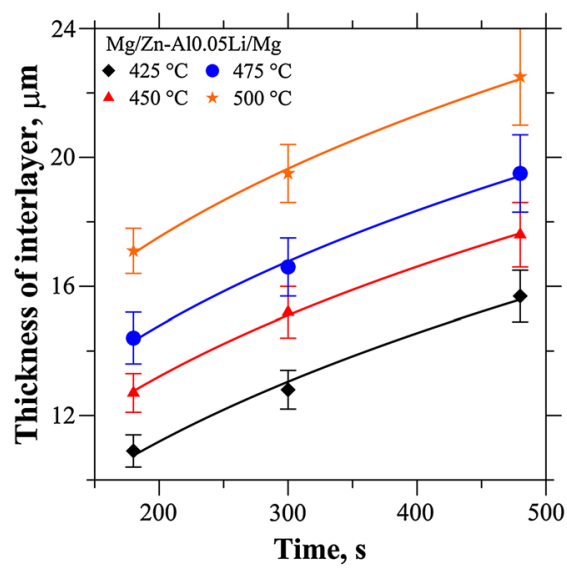

(b)

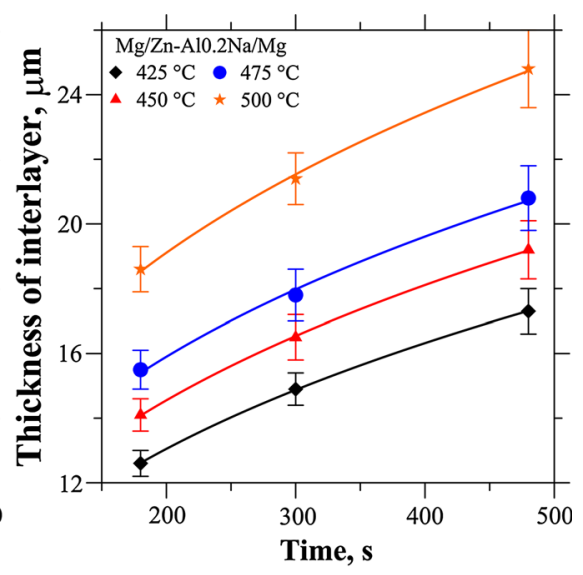

(c)

Fig. 4-Thickness of the interlayer at the interface after soldering process for (a) $\mathrm{Zn}-\mathrm{Al}$, (b) $\mathrm{Zn}-\mathrm{Al} 10.05 \mathrm{Li}$, (c) $\mathrm{Zn}-\mathrm{Al}$.2Na, respectively, as a function of time for different temperatures.

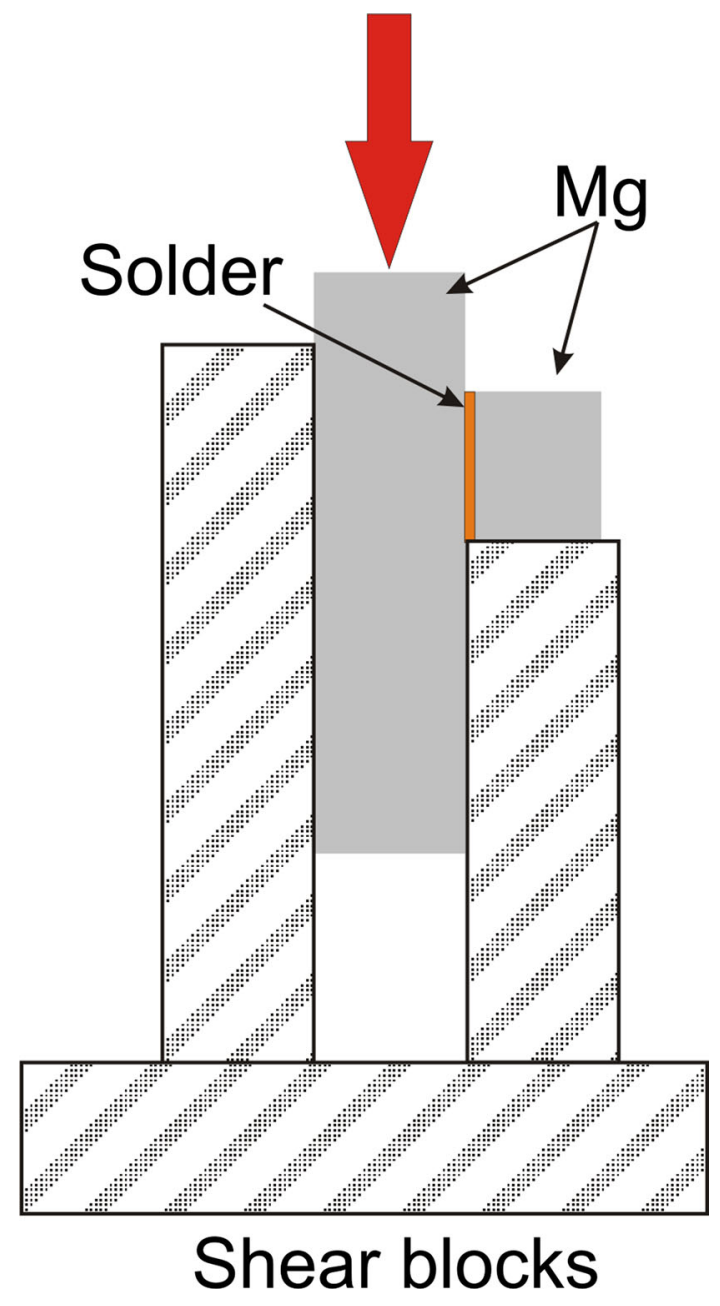

Fig. 5-Device and samples for shear strength measurements.

interface reaction area, which results in the $\mathrm{Mg}$ substrate being dissolved by solders at the high temperature of $500{ }^{\circ} \mathrm{C}$.
Table IV shows the microhardness of eutectic $\mathrm{Zn}-\mathrm{Al}$ and $\mathrm{Zn}-\mathrm{Al}$ alloys with $\mathrm{Li}$ and $\mathrm{Na}$ on $\mathrm{Mg}$ substrate. The two regions investigated were the $\alpha-\mathrm{Mg}+\mathrm{MgZn}$ eutectoid structure and the $\alpha-\mathrm{Mg}$ solid solution. The average microhardnesses obtained for the $\alpha-\mathrm{Mg}$ region were 103 , 104 , and $101\left(\mathrm{HV}_{0.05}\right)$ for eutectic $\mathrm{Zn}-\mathrm{Al}$, and $\mathrm{Zn}-\mathrm{Al}$ with $\mathrm{Li}$ and $\mathrm{Na}$, respectively. The microhardness of the $\alpha-\mathrm{Mg}$ region was related to the amount of doped $\mathrm{Zn}$ and Al, which was shown in the EDS analysis collected in Tables I through III. The average microhardnesses obtained for the $\alpha-\mathrm{Mg}+\mathrm{MgZn}$ region were 243, 233, and $237\left(\mathrm{HV}_{0.05}\right)$ for eutectic $\mathrm{Zn}-\mathrm{Al}$, and $\mathrm{Zn}-\mathrm{Al}$ with $\mathrm{Li}$ and $\mathrm{Na}$, respectively. The same situation as for the $\alpha-\mathrm{Mg}$ region occurs, so the addition of $\mathrm{Li}$ and $\mathrm{Na}$ increase microhardness to $67.2^{[13]}$ and 56.6 $6^{[14]}\left(\mathrm{HV}_{0.05}\right)$, respectively, compared to eutectic $\mathrm{Zn}-\mathrm{Al} \quad(55.0$ $\left.\left(\mathrm{HV}_{0.05}\right)^{[13]}\right)$. However, the greater addition of $\mathrm{Na}$ to eutectic $\mathrm{Zn}$-Al caused the creation of an area of doped $\mathrm{NaZn}_{13}$, where the microhardness is much higher (for $\mathrm{Na}$ (3 wt pct) it is $\left.339.0\left(\mathrm{HV}_{0.05}\right)^{[13]}\right)$. In the case of soldering AZ31 using the Zn-Al filler metal, ${ }^{[19]}$ the average microhardness values obtained at the interface of the $\alpha-\mathrm{Mg}$ solid solution and $\alpha-\mathrm{Mg}+\mathrm{MgZn}$ eutectoid structure are 93 and $134\left(\mathrm{HV}_{0.05}\right)$, respectively, compared to $81\left(\mathrm{HV}_{0.05}\right)$ and $130\left(\mathrm{HV}_{0.05}\right)$, respectively, for $\mathrm{Zn}-\mathrm{Mg}-\mathrm{Al}$ solder, which is much lower than for the $\alpha-\mathrm{Mg}+\mathrm{MgZn}$ region result obtained by this study.

\section{DISCUSSION}

During the soldering process, $\mathrm{Zn}-\mathrm{Al}$ solders and the $\mathrm{Mg}$ substrate formed an interfacial layer at the interface. This is a diffusion layer, where the $\alpha$-Mg solid solution is contained by $\mathrm{Zn}$ and Al. Such behavior was observed for solder materials of the $\mathrm{Zn}-\mathrm{Al}$ system, ${ }^{[18]}$ $\mathrm{Zn}-\mathrm{Mg}-\mathrm{Al},{ }^{[23]} \mathrm{Zn}-\mathrm{Mg},{ }^{[9]}$ and $\mathrm{Sn}-\mathrm{Zn} .{ }^{[10]}$ The $\mathrm{Mg}$ substrate dissolves more easily compared to a $\mathrm{Cu}$ substrate ${ }^{[15-18]}$ and the kinetics of creation of the IMC layer are different. However, the interlayer after soldering for 8 minutes at a temperature of $500{ }^{\circ} \mathrm{C}$ is not as thick as 


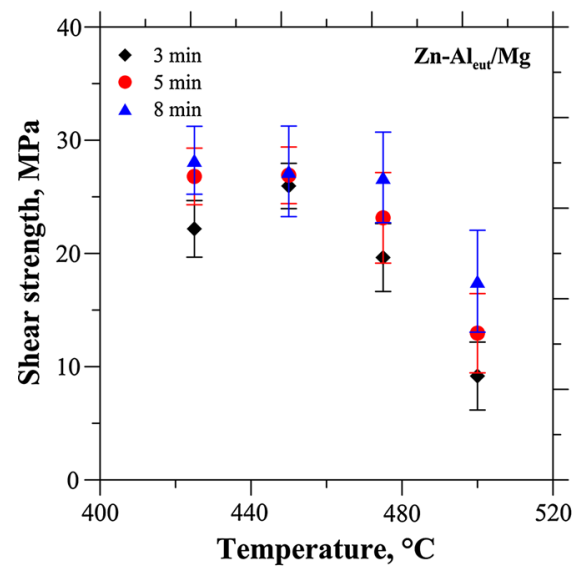

(a)

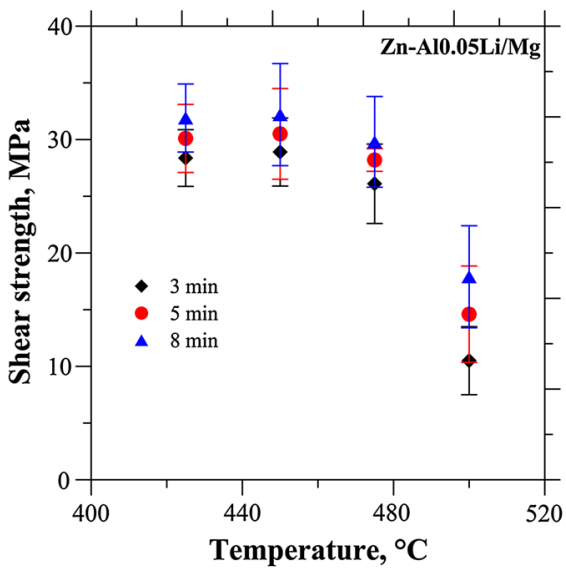

(b)

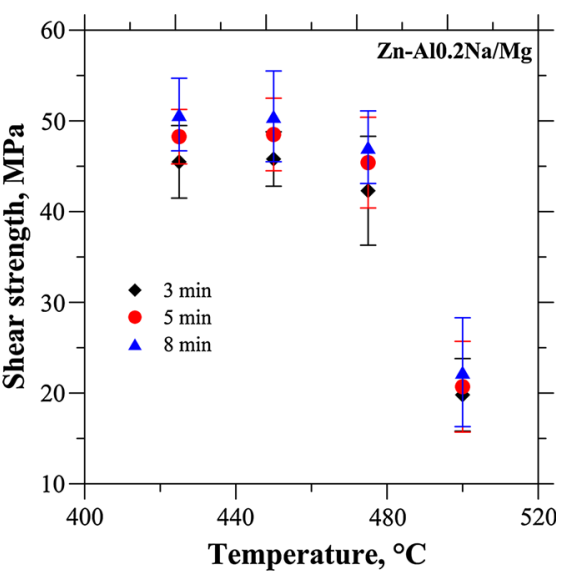

(c)

Fig. 6- Shear strength of joints for (a) eutectic Zn-Al, (b) Zn-Al0.05Li, and (c) Zn-Al0.2Na, respectively.

Table IV. Microhardness Value Obtained at the Interface of Mg Joints for Eutectic Zn-Al, Zn-Al0.05Li, and Zn-Al0.2Na Alloys

\begin{tabular}{lcc}
\hline & \multicolumn{2}{c}{ Microhardness (HV) } \\
\cline { 2 - 3 } Alloys & $\alpha$-Mg Region & $\alpha-\mathrm{Mg}+$ MgZn Region \\
\hline Zn-Al. & $103 \pm 4$ & $243 \pm 7$ \\
Zn-A10.05Li & $104 \pm 4$ & $233 \pm 2$ \\
Zn-A10.2Na & $101 \pm 3$ & $237 \pm 11$ \\
\hline
\end{tabular}

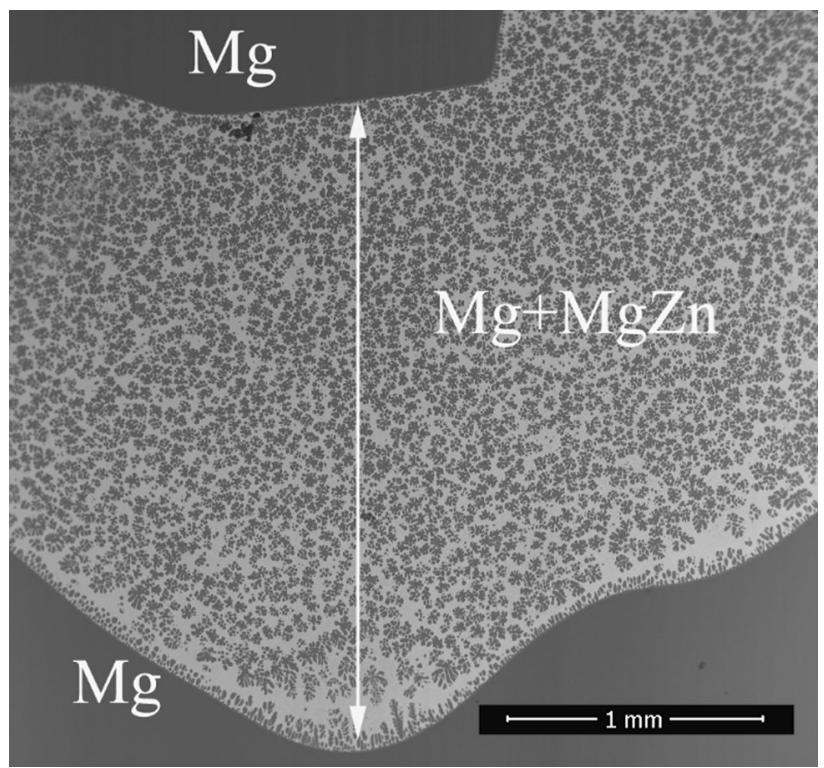

Fig. 7-Microstructures of eutectic $\mathrm{Zn}-\mathrm{Al}$ with $\mathrm{Mg}$ substrates joints after soldering at a temperature of $475^{\circ} \mathrm{C}$ for $8 \mathrm{~min}$.

that of the same solder used for soldering $\mathrm{Cu}(87.1 \mu \mathrm{m}$ for $\mathrm{Zn}-\mathrm{Al},{ }^{[24]} 85.5 \mu \mathrm{m}$ for $\mathrm{Zn}-\mathrm{A} 10.05 \mathrm{Li}^{[15]}$ and $79.3 \mu \mathrm{m}$ for $\mathrm{Zn}-\mathrm{Al} 0.2 \mathrm{Na},{ }^{[16]}$ compared to this study: 19.4, 22.5 , and $24.8 \mu \mathrm{m}$, respectively). In the case of the $\mathrm{Cu}$ substrate, three IMCs $\varepsilon-\mathrm{CuZn}_{4}, \gamma-\mathrm{Cu}_{5} \mathrm{Zn}_{8}$, and
$\beta-\mathrm{CuZn}$ are formed at the interface during soldering, causing the pure $\mathrm{Cu}$ to dissolve in the solder but only as particles of $\varepsilon$, which could with time transform to the $\gamma$ phase as the phase with lower Gibbs free energy. ${ }^{[16,25,26]}$ The observed microstructure of $\mathrm{Mg}$ joints (Figures 1, 2 and 3) shows that the $\mathrm{Mg}$ from the substrate dissolved in the solder as particles of $\mathrm{Mg}$ (EDS points: 6, 9, 10, 17, 19 , and so on), and as the matrix of solder $\alpha-\mathrm{Mg}+$ MgZn (area EDS: 4, 5, 11, 12, 16, 18, and so on). The solder's chemical composition transforms from the $\mathrm{Zn}-\mathrm{Al}$ system to the $\mathrm{Mg}-\mathrm{Zn}$ system in the event of diffusion of $\mathrm{Mg}$ from the substrate. A different character of changes is observed for $\mathrm{Cu}$ joints, ${ }^{[18]}$ where the $\mathrm{Cu}$ dissolves in the solder but the matrix of the solder is still the $\mathrm{Zn}-\mathrm{Al}$ system. For such changes, temperature controls the reaction when soldering on $\mathrm{Mg}$ substrate. For the $\mathrm{Mg}-\mathrm{Zn}$ system, ${ }^{[19]}$ the temperature of the soldering process is above that of eutectic reaction, so the $\mathrm{Mg}$ will dissolve faster in the solder. As observed in References 2, 23, and 24 and in our study, the $\mathrm{Mg}$ substrate is dissolved in the solder in its entirety, and the amount of $\mathrm{Mg}$ increased with increasing soldering time. The results show that the relative content of $\mathrm{Al}$ and $\mathrm{Zn}$ elements in the solder decreases. The $\mathrm{Mg}$ substrate dissolves in a similar manner as in the dissolving $\varepsilon$ phase in the solder, with "scallops" detaching from the interlayer and diffusing deeper in the solder. The amount of $\mathrm{Mg}$ in the solder matrix close to the interlayer was similar to the amount in Reference 10 in which the composition of the solder was 47.8 of $\mathrm{Mg}, 48.9$ of $\mathrm{Zn}$ and 3.3 of $\mathrm{Al}$ (wt pet), as it was in this study (EDS analysis, Tables I through III). However, as presented in Reference 10 , for soldering at $390{ }^{\circ} \mathrm{C}$ for 30 seconds, with solder composed of $97.7 \mathrm{Zn}, 0.8 \mathrm{Mg}, 1.1 \mathrm{Al}$ and 0.4 $\mathrm{Mn}$ (wt pct), the $\mathrm{Zn}$ reach region is observed within the solder. ${ }^{[10]}$ This changes with a higher amount of $\mathrm{Mg}$ in the solder (83.0 of $\mathrm{Zn}, 15.2$ of $\mathrm{Mg}, 1.3$ of $\mathrm{Al}$, and $0.5 \mathrm{Mn}$ (wt pct)), and the $\mathrm{Zn}$ reach region almost disappears at a slightly higher soldering temperature $\left(420^{\circ} \mathrm{C}\right)$. In this study, after 3 minutes and at a soldering temperature of $475{ }^{\circ} \mathrm{C}$, the chemical composition of solder was $\mathrm{Mg}+\mathrm{MgZn}$, as shown in Figure 7. 
As observed in Reference 10, the weld width (joint area) is increased from 378 to $722 \mu \mathrm{m}$, indicating that the diffusion of $\mathrm{Mg}$ is higher than that of $\mathrm{Zn}$ and $\mathrm{Al}$. However, the process of dissolution of the $\mathrm{Mg}$ substrate is very dynamic, as it happens spontaneously rather than uniformly, creating a place where there is a fast path of $\mathrm{Mg}$ diffusion to the solder (as shown in Figure 7). The model of microstructure evaluation of $\mathrm{Mg} / \mathrm{Zn} / \mathrm{Mg}$ joints was presented in Reference 27. At first, in the case of dissolving Mg substrate by $\mathrm{Zn}$, an interlayer starts to be created at the interface. The "scalloped" structure of the interlayer is correlated with the grain boundary penetration phenomenon: liquid would penetrate the grain boundary along the depth direction of the Mg-base metal, since the $\mathrm{Mg}$ atoms at the grain boundary had higher chemical potential than those in the grains. ${ }^{[28]}$ At higher temperatures, the diffusion coefficient of $\mathrm{Mg}$ increased exponentially, causing an increase in the $\mathrm{Mg}$ contained in the liquid and increasing the width of the $\mathrm{Mg}(\mathrm{Zn})$ diffusion layer. ${ }^{[27]}$ The same character of dissolving substrate and formation of "scallops" at the interface as that presented in the literature for $\mathrm{Cu}$ substrate with $\mathrm{Zn}-\mathrm{Al}$ alloys was observed. ${ }^{[15-18]}$ However, in the case of $\mathrm{Cu}$, three IMCs were formed at the interface and the process was controlled by the diffusion of $\mathrm{Cu}$ to the solder (Table IV).

Taking into account that the thickness of the IMC layer is correlated with diffusion and growth rate in the $\mathrm{Mg}$ joint, the character of growth rate changes from volume diffusion to grain boundary. However, a lot of $\mathrm{Mg}$ particles are observed in the solder. Similar microstructure and properties for $\mathrm{Mg}$ joints soldered with $\mathrm{Zn}$-based alloys were observed in the literature ${ }^{[9,19,23]}$ for Al-based filler metal. ${ }^{[2]}$ The diffusion layer at the interface is observed, and a huge amount of $\mathrm{Mg}$ dissolves in solder and changes its chemical composition to $\alpha-\mathrm{Mg}+\beta-\mathrm{Mg}_{17} \mathrm{Al}_{12}$. The results of the performed mechanical tests indicate that the average shear strength is $45 \mathrm{MPa} .{ }^{[24]}$ Furthermore, the fractographic analysis of the soldered $\mathrm{Mg}$ joint for both $\mathrm{Zn}$ and Al-based solder shows a brittle fracture pattern. ${ }^{[9,18,23,24]}$

The results of mechanical property testing showed that the addition of $\mathrm{Li}$ and $\mathrm{Na}$ increases the shear strength of $\mathrm{Mg}$ joints to $\sim 32$ and $\sim 50 \mathrm{MPa}$, respectively, compared to $28 \mathrm{MPa}$ for eutectic Zn-Al. Furthermore, the obtained shear strength is slightly higher compared to $19 \mathrm{MPa}^{[19]}$ for a $\mathrm{Zn}$-Al alloy filler with 19.2 (wt pct) Al. However, this is much lower compared to $70 \mathrm{MPa}$ for $\mathrm{Sn} 40 \mathrm{Zn}^{[10]}$ and $56 \mathrm{MPa}$ for $\mathrm{Mg} 3.0 \mathrm{Al1}$.0Zn0.4Mn0.1Si. ${ }^{[23]}$ Moreover, as was observed in all cases, the fracture proceeds from the eutectic $\alpha-\mathrm{Mg}+\mathrm{MgZn}$ region close to the interfacial layer. The observation in Reference 19 shows that the fracture of the soldered joint has a brittle pattern. The dissolution of $\mathrm{Al}$ and $\mathrm{Zn}$ in the $\alpha-\mathrm{Mg}$ has a solid solution strengthening effect, which improved the mechanical properties. The stress concentration effect in solder joints on $\mathrm{Mg}$ substrate accumulates in the $\alpha-\mathrm{Mg}+\mathrm{MgZn}$ eutectoid structure, where the fracture will start. The authors ${ }^{[19]}$ show that the high microhardness and brittleness of the $\alpha-$ $\mathrm{Mg}+\mathrm{MgZn}$ eutectoid structure in the case of $\mathrm{Zn}-\mathrm{Al}$ solder are the main reasons for the fracture of the soldered $\mathrm{Mg}$ joints. The fracture-causing high microhardness of the $\alpha-\mathrm{Mg}+\mathrm{MgZn}$ eutectoid structure is $134\left(\mathrm{HV}_{0.05}\right)$, compared to $93\left(\mathrm{HV}_{0.05}\right)^{[19]}$ for the $\alpha-\mathrm{Mg}$ solid solution. As presented in Reference 23 for Mg-based solder, the fracture of the joint exhibits intergranular features, and the crack originates from the $\alpha-\mathrm{Mg}+\mathrm{MgZn}$ eutectoid structure. The microhardness of the $\alpha-\mathrm{Mg}$ solid solution is $81\left(\mathrm{HV}_{0.05}\right)$, and that of the $\alpha-\mathrm{Mg}+\mathrm{MgZn}$ eutectoid structure is $130\left(\mathrm{HV}_{0.05}\right){ }^{\left[{ }^{23]}\right.}$ Where an external force acts on the solder joint, the stress concentration is generated easily from the hard $\alpha-\mathrm{Mg}+\mathrm{MgZn}$ eutectoid structure. ${ }^{[23]}$ The same effect as in the case of $\mathrm{Zn}-\mathrm{Al}^{[19]}$ and $\mathrm{Mg}$-based $^{[23]}$ solders was observed for Al-based solder, ${ }^{[24]}$ where the hard phase of $\beta-\mathrm{Mg}_{17} \mathrm{Al}_{12}$ (which is much harder than $\alpha-\mathrm{Mg}$, at $120\left(\mathrm{HV}_{0.05}\right)$ and $91\left(\mathrm{HV}_{0.05}\right)$, respectively) is responsible for the fracture. The same observation is made in Reference 8 - that, with increasing Al in Mg-Sn-In-Al, the hardness also increases, from $96\left(\mathrm{HV}_{0.05}\right)$ to $123\left(\mathrm{HV}_{0.05}\right)$ for 0 and 6 (wt pct) of Al, respectively. For the higher microhardness values for $\alpha-\operatorname{Mg}\left(\sim 100\left(\mathrm{HV}_{0.05}\right)\right)$ and $\alpha-\mathrm{Mg}+\operatorname{MgZn}(\sim 230$ $\left.\left(\mathrm{HV}_{0.05}\right)\right)$ obtained in this study, the fact that the soldering process was performed without flux had an impact. This could be compared with References 19 and 23, where soldering was carried out in the presence of QJ201 flux - which in our observations and measurements reduced the mechanical properties of the obtained joints.

\section{CONCLUSIONS}

Eutectic Zn-A1, Zn-A10.05Li, and Zn-A10.2Na alloys were designed to join pure magnesium substrate. The experiment shows the mechanism and morphology changes for $\mathrm{Mg}$, forming the basis of and explain the behavior of $\mathrm{Mg}$ when soldering $\mathrm{Mg}$ alloys. From this study, the following important conclusions were derived:

(1) Magnesium substrate can be successfully joined by eutectic $\mathrm{Zn}-\mathrm{Al}, \mathrm{Zn}-\mathrm{A} 10.05 \mathrm{Li}$, and $\mathrm{Zn}-\mathrm{A} 10.2 \mathrm{Na}$ alloys in an argon gas shield.

(2) The original solder, eutectic $\mathrm{Zn}-\mathrm{Al}, \mathrm{Zn}-\mathrm{A} 10.05 \mathrm{Li}$, and $\mathrm{Zn}-\mathrm{A} 10.2 \mathrm{Na}$ alloys were consumed after the soldering process. The cross section microstructure showed that $\alpha-\mathrm{Mg}+\mathrm{MgZn}$ eutectoid structures were formed in the soldering region.

(3) The average shear strengths are 28, 32, and $50 \mathrm{MPa}$ for eutectic $\mathrm{Zn}-\mathrm{Al}, \mathrm{Zn}-\mathrm{A} 10.05 \mathrm{Li}$, and $\mathrm{Zn}-\mathrm{A} 10.2 \mathrm{Na}$ alloys, respectively, for soldered $\mathrm{Mg}$ joints. The microhardness for the $\alpha-\mathrm{Mg}$ region is 103,104 , and $101\left(\mathrm{HV}_{0.05}\right)$, and for $\alpha-\mathrm{Mg}+\mathrm{MgZn}$ is 243, 233, and $237\left(\mathrm{HV}_{0.05}\right)$ for eutectic $\mathrm{Zn}-\mathrm{Al}, \mathrm{Zn}-\mathrm{A} 10.05 \mathrm{Li}$, and $\mathrm{Zn}-\mathrm{A} 10.2 \mathrm{Na}$, respectively. The fracture is intergranular, and the crack originates from the hard $\alpha-\mathrm{Mg}+\mathrm{MgZn}$ eutectoid structure.

\section{OPEN ACCESS}

This article is distributed under the terms of the Creative Commons Attribution 4.0 International License (http://creativecommons.org/licenses/by/4.0/), which permits unrestricted use, distribution, and reproduction in any medium, provided you give appropriate credit to the original author(s) and the source, provide a link to the Creative Commons license, and indicate if changes were made. 


\section{REFERENCES}

1. K.U. Kainer, ed., Magnesium Alloys and their Applications, ed., Wiley-Vch, New York, 2006.

2. A.A. Luo: Inter. Mater. Rev., 2004, vol. 49, pp. 13-30.

3. Y. Zhang, Z. Luo, Y. Li, Z.-M. Liu, and Z.-Y. Huang: Mat. Des., 2015, vol. 75, pp. 166-73.

4. J. Hirsch and T. Al-Samman: Acta Mater., 2013, vol. 61, pp. $818-43$.

5. M. Mezbahul-Islam, A.O. Mostafa, and M. Medraj: J. Mater., 2014, vol. 2014, pp. 1-33.

6. F. Hayat: Mater. Des., 2011, vol. 32, pp. 2476-84.

7. L.M. Zhao and Z.D. Zhang: Scr. Mater., 2008, vol. 58, pp. 283-86.

8. L.M. Liu and H.Y. Wang: Mater. Sci. Eng. A, 2009, vol. 507, pp. 22-28.

9. L. Liu and Z. Wu: Mater. Character., 2010, vol. 61, pp. 1318

10. Z. Wang, H. Wang, and L. Liu: Mat. Des., 2012, vol. 39, pp. 14-19.

11. T. Watanabe, 8 - Brazing and soldering of magnesium alloys, Welding and joining of magnesium alloys, (2010) 97-121.

12. M.K. Kulekci: Int. J. Adv. Manuf. Technol., 2008, vol. 39, pp. $851-65$.

13. T. Gancarz, G. Cempura, and W. Skuza: Mater. Charact., 2016 , vol. 111, pp. 147-53.

14. T. Gancarz and G. Cempura: Mater. Des., 2016, vol. 104, pp. $51-59$.
15. T. Gancarz, J. Pstrus, G. Cempura, and K. Berent: J. Electron. Mater., 2016, vol. 45, pp. 6067-78, https://doi.org/10.1007/s11664016-4815-8.

16. T. Gancarz and J. Pstruś: K. BerentJ. Mater. Eng. Perform., 2016, vol. 25, pp. 3366-74, https://doi.org/10.1007/s11665-016-2075-7.

17. J. Pstruś, P. Fima, and T. Gancarz: J. Mater. Eng. Perform., 2012, vol. 21 , pp. 606-13.

18. J. Pstrus and T. Gancarz: J. Mater. Eng. Perform., 2014, vol. 23, pp. 1614-24.

19. L. Ma, D.Y. He, X.Y. Li, and J.M. Jiang: Mater. Letter., 2010, vol. 64, pp. 596-98.

20. T. Massalski, H. Okamoto, P. Subramanian, and L. Kacprzak: Binary alloy phase diagrams, ASM International, Ohio, 2001, p. 2445.

21. J.R. Terbush, N. Stanford, J.-F. Nie, and M.R. Barnett: Metall. Mater. Trans. A, 2013, vol. 44A, pp. 5216-24.

22. M. Prażmowski: Arch. Metall. Mater., 2014, vol. 59, pp. 1137-42.

23. L. Ma, D. He, X. Li, and J. Jiang: J. Mater. Sci. Technol., 2010, vol. 26, pp. 743-46.

24. L. Ma, P. Qiaoa, W. Longa, D. Heb, and X. Lib: Mater. Des., 2012, vol. 37, pp. 465-69.

25. T. Gancarz, J. Pstrus, P. Fima, and S. Mosinska: J. Alloy Compd., 2014, vol. 582, pp. 313-22.

26. Y. Takaku, L. Felicia, I. Ohnuma, R. Kainuma, and K. Ishida: $J$. Electron. Mater., 2008, vol. 37, pp. 314-23.

27. R. Xie, X. Chen, Z. Lai, L. Liu, G. Zou, J. Yan, and W. Wang: Mater. Des., 2016, vol. 91, pp. 19-27.

28. M.F. Wu, C. Yu, and J. Pu: Mater. Sci. Technol., 2008, vol. 24, pp. $1422-26$ 